\title{
Professional Competence as an Essential Characteristic of a University Student's Personality
}

\author{
Olga Makarova ${ }^{1,}{ }^{*}$ Margarita Kovardakova ${ }^{1}$, Anastasia Shabanova ${ }^{1}$ \\ ${ }^{1}$ Ulyanovsk State University, Ulyanovsk, Russia \\ "Email: makarova_olia_84@mail.ru
}

\begin{abstract}
The social demand of modern society requires graduates from universities with a certain level of qualifications. Such a level implies both educational background and the development of personal qualities necessary for the performance of professional activities and the adaptation to the changing conditions of the modern market economy.

The paper deals with professional competence as a main measurable indicator of the educational goal at universities. The authors pursued the answers if 1) the level of professional competence and the development of student's personality are interrelated, 2) it is possible to measure personal characteristics, and 3) it is possible to improve the efficiency of the educational process by means, for instance, of situational tasks on the foreign (English) language classes, applying the interdisciplinary approach. The authors describe the techniques that allow overseeing the process of building professional competence alongside developing a student's personality, both qualitatively and quantitatively. That was supposed to test empirically due to the experiment involving the first-year lawyer-students of Ulyanovsk State University.

The experiment was conducted in foreign language (English) classes, during which the students of the experimental group were offered situational tasks and exercises, cases and other elements of the situational approach.

The authors define the interrelation between the notions "competence", "experience", including from the standpoint of the future employer. The article presents the alternative to professional competence (personal potential) as a teaching goal. As a result, the authors conclude that the personal component is of great importance, as it is connected with the motivational sphere of a future specialist. The research showed the efficiency of the interdisciplinary approach (including the personally professional component), thanks to which building students' professional competence takes place more effectively.
\end{abstract}

Keywords: Professional competence, Personality, Situational approach, Personal potential, Components of professional competence, Legal specialist, Learning process.

\section{INTRODUCTION}

The growth of international relations at various levels has enhanced the role of the legal sphere due to what the social demand for legal specialists has increased. The extension of digital communication space has also expanded the law enforcement area. This has imposed additional obligations on higher educational institutions to train the students of legal specialities. These facts stipulated the relevance of the chosen theme.
Most countries have professional standards for lawyers, which regulate the rules of professional conduct. Namely, the US Supreme courts issue rules and regulations for professional standards of conduct (The Rules of Professional Conduct), in Great Britain, it is the SRA Code of Conduct for Solicitors, RELs and RFLs, in Switzerland - Der Schweizerische Anwaltsverband (Swiss Bar Association), in Russia - Professional Standards.

Scientists define professional competence as a complex of personal attributes that allow gaining high quality and work efficiency [1]. For the continuous 
optimisation of business processes, such qualities as assertiveness, amenability and even system and creative work approach are essential. From this perspective, we demonstrate the social demand for the specialist who should possess two main groups of skills: the first defines him as a specialist of specific expertise, the second relates to the ability of self-development and elaborate the field of expertise using knowledge from other areas [2]. Besides, a highly qualified specialist must fully meet the professional code of conduct requirements that bring the moral and ethic component to the structure of professional competence of a student's personality who masters his profession at university [3].

Our study is devoted to developing the student's personality mastering Bachelor's degree in "Jurisprudence". The choice of the first stage of learning (freshman year) is well-reasoned, as most students leave university, particularly at this stage. For this reason, it is vital to assess the student's potential during the first year of training and probably help the student decide upon whether to go on to further study at the Department of Law or choose another professional area.
A legal specialist should possess specific skills divided into two groups. The first group includes general skills that can be built through teaching methods at university, such as critical and analytical thinking skills, communication skills, negotiation and problemsolving skills. The second group involves personal quality skills, which are challenging to master in the educational environment. To select personal attributes necessary for the specialists of the legal sector, we took into consideration the requirements imposed to job seekers for the positions in international organisations, materials available at Law school sites (for instance, Abraham Lincoln University), as well as scientific psychology and sociology articles that give scientific credence of the selected personal attributes (for instance, the work of Rachel Brooks) [4]. Such attributes involve advertence, self-control, equableness of mind.

Thus, we were interested in two sides of professional competence relevant to the legal sphere: components which can be built at university and the components peculiar for a student's personal qualities. Based on theoretical literature, we selected evaluation techniques and criteria for making the professional competence of a

Table 1. Dynamics of the main components of a personality's motivational complex

\begin{tabular}{|c|c|c|c|c|c|}
\hline \multirow[t]{2}{*}{ Groups } & & \multicolumn{2}{|c|}{ Summative stage } & \multicolumn{2}{|c|}{ Formative stage } \\
\hline & & $\begin{array}{c}\text { Experimental } \\
\text { group }\end{array}$ & Control group & $\begin{array}{c}\text { Experimental } \\
\text { group }\end{array}$ & Control group \\
\hline \multirow{5}{*}{ Internal motivation } & 1 & $38,9 \%$ & $37,1 \%$ & $15,7 \%$ & $33,3 \%$ \\
\hline & 2 & $28,7 \%$ & $30,5 \%$ & $14,8 \%$ & $28,6 \%$ \\
\hline & 3 & $18,5 \%$ & $22,9 \%$ & $24,1 \%$ & $25,7 \%$ \\
\hline & 4 & $11,1 \%$ & $8,6 \%$ & $26,9 \%$ & $9,5 \%$ \\
\hline & 5 & $2,8 \%$ & $0,9 \%$ & $18,5 \%$ & $2,9 \%$ \\
\hline \multirow{5}{*}{ Internal positive motivation } & 1 & $37,9 \%$ & $38,1 \%$ & $21,3 \%$ & $36,2 \%$ \\
\hline & 2 & $30,6 \%$ & $32,4 \%$ & $16,7 \%$ & $29,5 \%$ \\
\hline & 3 & $16,6 \%$ & $15,2 \%$ & $14,8 \%$ & $16,2 \%$ \\
\hline & 4 & $9,3 \%$ & $7,6 \%$ & $31,5 \%$ & $7,6 \%$ \\
\hline & 5 & $5,6 \%$ & $6,7 \%$ & $15,7 \%$ & $10,5 \%$ \\
\hline \multirow{5}{*}{ Internal negative motivation } & 1 & $14,8 \%$ & $13,3 \%$ & $23,1 \%$ & $16,2 \%$ \\
\hline & 2 & $22,2 \%$ & $20,9 \%$ & $30,6 \%$ & $21,9 \%$ \\
\hline & 3 & $23,2 \%$ & $22,9 \%$ & $24,1 \%$ & $23,8 \%$ \\
\hline & 4 & $23,2 \%$ & $24,8 \%$ & $13,9 \%$ & $20,9 \%$ \\
\hline & 5 & $16,6 \%$ & $18,1 \%$ & $8,3 \%$ & $17,2 \%$ \\
\hline
\end{tabular}


Table 2. Dynamics of students' life values in the professional life

\begin{tabular}{|c|c|c|c|c|}
\hline \multirow{2}{*}{ Groups } & \multicolumn{2}{|c|}{ Summative stage } & \multicolumn{2}{c|}{ Formative stage } \\
\cline { 2 - 5 } & $\begin{array}{c}\text { Experimental } \\
\text { group }\end{array}$ & Control group & $\begin{array}{c}\text { Experimental } \\
\text { group }\end{array}$ & Control group \\
\hline low & $16,9 \%$ & $16,3 \%$ & $6,7 \%$ & $12,2 \%$ \\
\hline middle & $43,4 \%$ & $47,5 \%$ & $37,1 \%$ & $49,2 \%$ \\
\hline high & $39,7 \%$ & $36,2 \%$ & $56,2 \%$ & $38,6 \%$ \\
\hline
\end{tabular}

future legal specialist.

\section{METHODS}

The personality development of a law student can be assayed in terms of 5 criteria (motivational and valuebased, cognitive, activity practical, professionalcommunicative, and personally-professional). To measure each of the criteria, we selected two ways of obtaining quantitative data. The article presents only processed data for the summative and formative stages.

In the experiment, we applied situational tasks to an interdisciplinary approach to foreign (English) language classes. The importance of the interdisciplinary approach was, for instance, demonstrated by experiments in work by Lockemer [5]. The discipline "Foreign language" was chosen because a foreign is considered as the primary means of receiving live information. The choice of the freshman year for the experiment is conditioned by the fact that the students become acquainted with the legal profession and area of law at this particular time. Besides, at this stage, they reassess their interests.

The work with students was carried out using questionnaires, tests and personal interviews. The data obtained were processed with both mathematical and statistical ways of data analysis [6]. Four levels of professional competence formedness of students were obtained: potential, adaptive, normative, and advanced. In terms of criteria, we measured the professional competence levels formed by future lawyers at different stages.

The empiric research was conducted in the Federal State-Funded Educational Institution "Ulyanovsk State University". The participants were 213 people enrolled on the first course of speciality "Jurisprudence" in 2017. At the given stage, we did not consider the gender and age differences of the students in each of the groups. Therefore, statistical data of such parameters are missing.

Control group students followed the curriculum. The experimental group students were offered additional materials, sometimes the substitution of common tasks into those of situational nature. Before filling up the questionnaires, the students were informed about anonymity, confidentiality and voluntary participation.

The additional information was obtained from the students in oral form. The students' answers were analysed in terms of emotional response to various new components introduced in class.

\section{DISCUSSION}

In the last few decades, the employer has focused on the competencies of staff members. Under regulations of large companies, each staff member had to obtain a

Table 3. Dynamics of students' life values in the social life

\begin{tabular}{|c|c|c|c|c|}
\hline \multirow[t]{2}{*}{ Groups } & \multicolumn{2}{|c|}{ Summative stage } & \multicolumn{2}{|c|}{$\overline{\text { Formative stage }}$} \\
\hline & $\begin{array}{l}\text { Experimental } \\
\text { group }\end{array}$ & Control group & $\begin{array}{l}\text { Experimental } \\
\text { group }\end{array}$ & Control group \\
\hline Low & $19,9 \%$ & $19,4 \%$ & $6,4 \%$ & $13,8 \%$ \\
\hline Middle & $56,9 \%$ & $55,9 \%$ & $51,2 \%$ & $58,1 \%$ \\
\hline High & $23,4 \%$ & $24,7 \%$ & $42,4 \%$ & $28,1 \%$ \\
\hline
\end{tabular}


Table 4. Dynamics of the respondents' legal thinking

\begin{tabular}{|c|c|c|c|c|}
\hline \multirow{2}{*}{ Levels } & \multicolumn{2}{|c|}{ Summative stage } & \multicolumn{2}{c|}{ Formative stage } \\
\cline { 2 - 4 } & $\begin{array}{c}\text { Experimental } \\
\text { group }\end{array}$ & Control group & $\begin{array}{c}\text { Experimental } \\
\text { group }\end{array}$ & \begin{tabular}{c} 
Control group \\
\hline low
\end{tabular} \\
\hline satisfactory & $25,0 \%$ & $29,5 \%$ & $2,8 \%$ & $18,0 \%$ \\
\hline optimum & $13,9 \%$ & $59,1 \%$ & $24,1 \%$ & $59,1 \%$ \\
\hline high & $0,9 \%$ & $11,4 \%$ & $56,5 \%$ & $19,1 \%$ \\
\hline
\end{tabular}

certain set of competencies depending on their position. The recruitment was based on the list of competencies. However, such recruitment has become insufficient at the present day, as the employer needs specialists who possess the problem-solving skills and the potential to gain new knowledge and experience necessary in present-day conditions. At present, HR specialists of the legal sphere prepare for candidates the list consisting of two equal-value groups of skills: hard and soft skills. Notably, the last is called "competencies of future". Due to the significance of both components, the skills referred to as work experience in legal expertise are relatively valuable. At the present day, some employers demand specialists with related field knowledge. A notable example of this fact is the work of lawyers. Legal specialists must possess specific knowledge and value system, and worldview approaches. For instance, Margaret Martin Barry, in her work apply the treecomponent model, where the lawyers training results are measured concerning such groups of markers as knowledge, skills, values [7]

Job performance also depends on the motivation and personal ambitions of the specialist. Skills, experience, knowledge, and abilities are part of competence [8]. To prepare a sought-after specialist, it is crucial to develop proper criterion characteristics and scores in the higher education system that monitors the process of building students' professional competence during the whole academic course.

Scientists indicate a various number of competencies. Rakhmonov A.B. includes «knowledge, abilities, possession, and personal characteristics in their structure» [9]. Yu.G. Tatur generalised all the components into three groups: cognitive, activity-based and value-based [10]. This study operates motivational, value-based, cognitive, practical, professionalcommunicative, and personally-professional components. For each of the components, we selected a specific evaluation method.

Based on the presented theoretical ground, the study tested the following hypotheses:

1. the building of professional competence is inextricably linked with the development of student's personality;

2. personal characteristics of a student can be measured, as well as the forming components of professional competence;

3. development of the student's personality and his professional attributes and competencies can be improved due to the interdisciplinary approach.

Table 5. Dynamics of cognitive potential of study

\begin{tabular}{|c|c|c|c|c|}
\hline \multirow{2}{*}{ Groups } & \multicolumn{2}{|c|}{ Summative stage } & \multicolumn{2}{c|}{ Formative stage } \\
\cline { 2 - 5 } & $\begin{array}{c}\text { Experimental } \\
\text { group }\end{array}$ & Control group & $\begin{array}{c}\text { Experimental } \\
\text { group }\end{array}$ & Control group \\
\hline low & $36,2 \%$ & $34,3 \%$ & $13,9 \%$ & $18,1 \%$ \\
\hline middle & $54,6 \%$ & $54,3 \%$ & $59,3 \%$ & $61,9 \%$ \\
\hline high & $9,2 \%$ & $11,4 \%$ & $26,8 \%$ & $20,0 \%$ \\
\hline
\end{tabular}


Table 6. Dynamics of foreign language levels

\begin{tabular}{|c|c|c|c|c|}
\hline \multirow{2}{*}{ Groups } & \multicolumn{2}{|c|}{ Summative stage } & \multicolumn{2}{c|}{ Formative stage } \\
\cline { 2 - 5 } & $\begin{array}{c}\text { Experimental } \\
\text { group }\end{array}$ & $\begin{array}{c}\text { Control } \\
\text { group }\end{array}$ & $\begin{array}{c}\text { Experimental } \\
\text { group }\end{array}$ & $\begin{array}{c}\text { Control } \\
\text { group }\end{array}$ \\
\hline extremely low & $45,4 \%$ & $50,5 \%$ & $4,6 \%$ & $16,2 \%$ \\
\hline low & $35,2 \%$ & $32,4 \%$ & $33,3 \%$ & $47,6 \%$ \\
\hline middle & $15,7 \%$ & $11,4 \%$ & $34,3 \%$ & $26,7 \%$ \\
\hline high & $3,7 \%$ & $4,7 \%$ & $17,6 \%$ & $7,6 \%$ \\
\hline very high & $0 \%$ & $1 \%$ & $10,2 \%$ & $1,9 \%$ \\
\hline
\end{tabular}

To diagnose the formation level of motivational and value-based criteria in the students of the Law department, we used the technique for determining the motivation for professional activity by $\mathrm{K}$. Zamfir (modified by A. Rean) and the morphologic test of life values by V.F. Sopov and L.V. Karpushina.

The first technique is based on the concept of two types of personal motivation: external and internal. External motives include external positive motives (EPM) and external negative motives (ENM). The group of external positive motives is more favourable and effective than external negative ones. The interrelation and inter influence of both groups of motivation is described by Richard M. Ryan, Edward L. Deci [11].

Quantitative results define the level of a personality's motivational complex that correlates with certain types of motivation: IM (internal motivation), IPM and INM. The best motivational complexes are the correlations IM $>$ IPM $>$ INM and IM = IPM $>$ ENM, when the worst are INM $>$ IPM $>$ IM.

Grouping the students into the formation levels of components of the motivational complex obtained in the experiment is presented in Table 1.

Comparison of types of motivation in the experimental group at the summative and formative stages showed an increase in internal positive motivation for the legal activities.

The second technique that indicated the respondents' values was the morphologic test of life values by V.F. Sopova, and L.V. Karpushina. To study the values of future lawyers, the two spheres were chosen: professional and social life. The obtained data show that the respondents have little interest in the legal profession. The students need professional development, but self-centred and prestigious values prevail. This is because of, for one part, age and missing the involvement in professional activities. For the other part, students are the prospective echelon of lawyers, and the absence of value basis of professional occupation might adversely influence its quality.

The dynamics of formation levels of students' life values in the sphere of professional life is presented in Table 2 .

The results in both groups at the summative stage in the sphere "Social life" are closely spaced. Average data $(56 \%)$ is specific for more than half of the respondents. This points to the balance of the moral-commercial and egoistic-prestige system of values. At the formative stage, grouping the respondents into the values of social life shows that building the professional competence of

Table 7. Dynamics of ability to solve situational tasks

\begin{tabular}{|c|c|c|c|c|}
\hline \multirow[t]{2}{*}{ Groups } & \multicolumn{2}{|c|}{ Summative stage } & \multicolumn{2}{|c|}{ Formative stage } \\
\hline & $\begin{array}{c}\text { Experimental } \\
\text { group }\end{array}$ & Control group & $\begin{array}{c}\text { Experimental } \\
\text { group }\end{array}$ & Control group \\
\hline low & $69,4 \%$ & $72,3 \%$ & $9,3 \%$ & $40,9 \%$ \\
\hline middle & $26,9 \%$ & $24,8 \%$ & $61,1 \%$ & $48,6 \%$ \\
\hline high & $3,7 \%$ & $2,9 \%$ & $29,6 \%$ & $10,5 \%$ \\
\hline
\end{tabular}


Table 8. Dynamics of communicative and organising skills

\begin{tabular}{|c|c|c|c|c|}
\hline \multirow{2}{*}{ Groups } & \multicolumn{2}{|c|}{ Summative stage } & \multicolumn{2}{c|}{ Formative stage } \\
\cline { 2 - 5 } & $\begin{array}{c}\text { Experimental } \\
\text { group }\end{array}$ & Control group & $\begin{array}{c}\text { Experimental } \\
\text { group }\end{array}$ & $\begin{array}{c}\text { Control } \\
\text { group }\end{array}$ \\
\hline low & $25,9 \%$ & $19,1 \%$ & $6,4 \%$ & $12,3 \%$ \\
\hline lower-middle & $40,8 \%$ & $48,5 \%$ & $22,2 \%$ & $37,1 \%$ \\
\hline middle & $24,1 \%$ & $21,9 \%$ & $26,9 \%$ & $21,0 \%$ \\
\hline upper-middle & $4,6 \%$ & $5,7 \%$ & $31,5 \%$ & $8,6 \%$ \\
\hline high & $4,6 \%$ & $4,8 \%$ & $13,0 \%$ & $21,0 \%$ \\
\hline
\end{tabular}

law students in the process of studying a foreign language based on an interdisciplinary approach (namely the situational approach) allowed increasing the number of students (see Table 3) with a high level of internal motivation, that indicates the humanistic growth of a student's personality.

Summarising the diagnostic assessment of the students' value sphere, it should be noted that personal values reflect the efficiency of acquiring and accepting the social norms. The dynamics of students' values in the experimental group proves its effectiveness.

To measure the cognitive component of professional competence, we used the test for determining the level of legal and civil thinking and the methodology for assessing cognitive potential in teaching by N.I. Shevandrin. To evaluate the level of legal thinking, the students were offered a test consisting of 13 statements. The results presented in Table 4 show that the number of students with a low grade of legal thinking decreased in both groups.

At the formative stage of the experiment, the retesting suggested the changes in legal thinking formedness in both experimental and control groups. Analysis of the results presented in Table 4 confirms that at the end of the experiment, the level of legal thinking of experimental group students is notably higher than in the control group.

To assess the cognitive potential in studying, we used the methodology by N.I. Shevandrin. The data presented in Table 5 confirm that the formedness of cognitive potential in studying in both experimental and control groups are almost the same.

The diagnosis of the activity-practical criterion of future lawyers' professional competence was performed based on English applying lexico-grammatical test and case study [12]. Criterial characteristics involve the ability to get necessary legal information in a foreign language (reading for specific details), skill to analyse and marshal the legal information in a foreign language, ability to apply the knowledge in practice (in the professional legal sphere), ability to logically state the thoughts in a foreign language in the course of professional activities, ability to acquire, understand and use professional-legal lexis and phraseology.

At the summative and formative stages of the experiment, the students performed a lexicogrammatical test that contained both common and legal lexis and grammar structures peculiar for formal legal texts, corresponding with an English degree course scheme for non-language specialities. The results

Table 9. Dynamics of social skills

\begin{tabular}{|c|c|c|c|c|}
\hline \multirow{2}{*}{ Groups } & \multicolumn{2}{|c|}{ Summative stage } & \multicolumn{2}{c|}{ Formative stage } \\
\cline { 2 - 5 } & $\begin{array}{c}\text { Experimental } \\
\text { group }\end{array}$ & Control group & $\begin{array}{c}\text { Experimental } \\
\text { group }\end{array}$ & Control group \\
\hline Low & $58,3 \%$ & $63,8 \%$ & $20,4 \%$ & $56,2 \%$ \\
\hline Normal & $26,9 \%$ & $24,8 \%$ & $61,1 \%$ & $30,5 \%$ \\
\hline High & $14,8 \%$ & $11,4 \%$ & $18,5 \%$ & $13,3 \%$ \\
\hline
\end{tabular}


Table 10. Dynamics of self-evaluation of professionally relevant qualities

\begin{tabular}{|c|c|c|c|c|}
\hline \multirow{2}{*}{ Groups } & \multicolumn{2}{|c|}{ Summative stage } & \multicolumn{2}{c|}{ Formative stage } \\
\cline { 2 - 5 } & $\begin{array}{c}\text { Experimental } \\
\text { group }\end{array}$ & Control group & $\begin{array}{c}\text { Experimental } \\
\text { group }\end{array}$ & Control group \\
\hline low & $48,2 \%$ & $50,5 \%$ & $14,8 \%$ & $33,3 \%$ \\
\hline middle & $33,3 \%$ & $37,1 \%$ & $57,4 \%$ & $50,5 \%$ \\
\hline high & $18,5 \%$ & $12,4 \%$ & $27,8 \%$ & $16,2 \%$ \\
\hline
\end{tabular}

presented in Table 6 show the positive dynamics in law students' foreign language. However, the experimental group students raised their level more significantly than the control group students.

Determining the level of the activity-practical criterion was also implemented using situational tasks and exercises [12]. In the research, we considered the proven efficiency of a certain coherence of tasks that can be applied in an educational process [13]. In the course of the experiment, we developed 12 criteria of assessment and their solution: scope of knowledge, both legal and lexical-grammatical; ability to integrate and structure information; using the acquired knowledge in practice; coherence and consistency in presenting arguments; a way of decision making; ability to reveal the main conditions of a problem; commitment and selfdependence in decision-making; ability to specify the problem-solving proposals based on conditions of a problem and gathered information; ability to predict the consequence of proposed solutions; ability to work in a group; adequateness of self-judgment; motivation to study and self-improve.

At the formative stage of the experiment, the number of students for all the criteria increased in both groups (see Table 7).

To determine the level of formedness of the professional-communicative level of law students' professional competence, we applied the communication and organising skills questionnaire by V.V. Sinyavskiy and V.A. Fedorishin and the questionnaire for developing the level of communication by V.F. Ryakhovskoy. It is obvious that the legal profession is directly connected with communication. Whether a lawyer addresses directly to the interlocutor or engages third parties, he is always involved in the process of interpersonal communication.

The data presented in Table 8 show that students' communicative and organising skills in the experimental group are higher. This is because the students solved situational tasks and exercises developed their communicative skills.

To determine the communication level, we applied the questionnaire by V.F. Ryakhovskoy. Maximum points and minimum points are negative for students of legal speciality. In this connection, maximum points imply the difficulty in interpersonal communication. Whereas excessively social people are often talkative, impulsive and unrestrainable, that is unacceptable in the legal sphere.

As presented in Table 9, the indicator of the average level in the experimental group increased due to the teamwork practice in solving situational tasks.

The diagnostics of formedness of personallyprofessional criteria was implemented using the questionnaire purposely designed in the experiment. In the self-esteem questionnaire, the students were offered 25 professionally relevant personality qualities of a lawyer taken from the documents of Solicitors Regulation Authority (SRA) [14]. Data analysis at the summative stage of the experiment (see Table 10) revealed that the students of both groups valued their professionally relevant personality qualities at a low rate.

\section{RESULTS}

Statistical analysis and mathematical calculation revealed the levels of professional competence of law students according to the rising gradation scale. They are as follows: potential, adaptive, normative and advanced.

At the potential level, the students' knowledge is fragmentary. Some students are aware of work aspects, but systemic knowledge is missing. The apprehension of professional competence is missing as well. The students are not able to conduct a dialogue in a foreign language. 
At the adaptive level, the student gains knowledge about the legal system. The student can issue a request and find information in a foreign language and perform an activity referring to legal practice strictly following the studied pattern.

At the normative level, the student already has a comprehensive idea of a legal system and can determine the chosen area of law. The student uses a foreign language for professional purposes, such as completion of forms, writing personal and business letters. The student has an idea of the legal sphere in other countries.

The distinctive characteristic of the advanced level is the ability of a student to apply the knowledge from different areas in the legal sphere, including that with the application of a foreign language. The student can find a solution in abnormal situations, performs a high level of moral and personal qualities necessary for a lawyer. The student is characterised by assertiveness and genuine interest in the chosen area and future profession and the desire to improve it. Grouping the respondents according to the levels of professional competence is presented in Figure 1.

Thus, competence is a personal characteristic. In the modern state standard framework, professional competence is considered a complex of personal qualities, knowledge, and skills that a future specialist should possess. All modern humanities prioritise personality and study the aspects of its functioning and building. To be successful and personally fulfilled, the individual should find his level going along with his needs. From this perspective, we talk about the two groups of competencies: professional and personal, mentioned in the State Educational Standard. Currently, human resources specialists in modern companies refer such competencies to hard and soft skills, which, in their turn, are often used in pedagogical and methodological

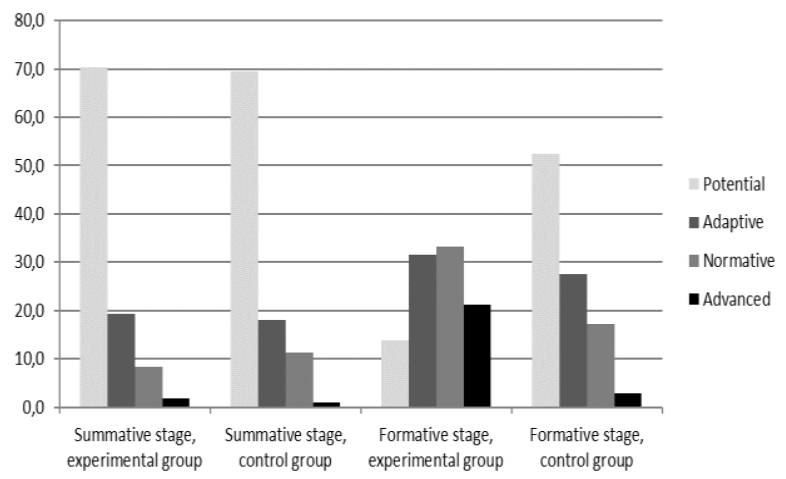

studies. This is because the education system should meet social requirements for specialists with certain qualities.

Figure 1 Grouping the respondents according to the levels of professional competence formedness in experimental and control groups.
Nevertheless, in general terms, such skills correlate with competencies approved in the State Educational Standard and can be built by comprehensible methods. The study results showed the formation of substantially all competencies, including of a personality nature. The interdisciplinary situational approach applied in the research proved that it could be the key working method at university, as it allows a teacher and students to evaluate the level of skills formedness, both qualitatively and quantitatively.

\section{CONCLUSION}

The goal of the higher education system is to train not only the future specialists in a specific field of expertise but also an all-around personality that can contribute to social development as a whole. Thus, it implies two parallel-interrelated processes: mastering the core knowledge and skills necessary for performing the future professional duties and the development of personal attributes necessary for further selfdevelopment, self-education, mental flexibility, and adaptation to the changing conditions of the labour and economic market.

Apparently, these goals are inextricably connected with the personality's fulfilment, motives, and natural abilities. At present, according to the current educational standards, such accumulation of informational capital involves the students' forming competencies.

At present, the focus of attention of the potential employer is shifting from hard skills to soft skills. Undoubtedly, such practical skills as system analytical capability, non-confrontational communication, and problem-solving skills are essential for an employer. However, the current labour market in the legal sphere demands from the specialist certain personal attributes such as professional motivation, critical thinking, and the ability to think creatively. Therefore, the search for quantitative evaluation of these skills has become one of the main tasks for both the HR specialists and teachers who must train sought-after specialists.

Some personal qualities are relevant to the legal sphere. Some of them (for example, honesty, scrupulosity, analytical-synthetical mentality) can be peculiar for the personality as such, independently of the chosen area of activities. Other personal qualities, such as a sense of responsibility, civil consciousness, critical thinking, resilience, professional intuition and others, are the indispensable attributes of a law specialist that must form and develop in the educational process.

From this perspective, it is necessary to use the interdisciplinary approaches that allow students to form the wider world views and acquire knowledge about the social realm as a system of interrelated components. 
The result of the study made it possible to reveal the personal attributes relevant to the legal profession and operational tools for quantitative evaluation. Besides, the researchers noted the positive dynamics of personal qualities of future legal specialists using an interdisciplinary approach in the educational process (technique based on the implication of situational tasks in the educational process, which are presented in a foreign (English) language and require the application of knowledge from different expertise.

The research shows that student personality is formed through two parallel processes: building professional competence and developing personal attributes. Both components should be considered conjunctively, as they are the integral characteristic of student personality. Besides, these two parts of the educational process inter influence each other. Notably, the second component (personal attributes) is more significant, as it constitutes the motivational sphere of an individual. Thus, the professional competence of a student can be changed and evaluated, and his personal qualities relevant to his future profession.

\section{REFERENCES}

[1] R.I. Burganovaa, S.E. Abdugalinaa, K.O. Shaikheslyamovaa, The Professional Competence Formation in the Training Process in Higher Educational Institution, In International Journal of environmental and science education 11(10) (2016) 3629-3639.

[2] L. Stepanenko, Actual Problems of Modern Pedagogy of Higher Education Advances in Social Science, Education and Humanities Research, In Humanities and Social Sciences: Novations, Problems, Prospects, 2019, p. 333.

[3] P. Joy, The Uneasy History of Experiential Education in U.S. Law Schools, 122 Dick. L. Rev., 2018, 551 p. Retrieved from: https://ideas.dickinsonlaw.psu.edu/dlr/vol122/iss2/ $\underline{4}$

[4] R. Brooks, Law and Psychology: Which Personality Types Suit the Role of Lawyer? Attorney at Law Magazine, 2019. Retrieved from: https://attorneyatlawmagazine.com/whichpersonality-types-suit-lawyer

[5] K. Lockemer, Law Students' Perspectives on Interdisciplinary Education: A Qualitative Study. Williams Honors College, Honors Research Projects, 2019, 913 p. Retrieved from: https://ideaexchange.uakron.edu/honors_research_ projects/913

[6] C. Maione, D. Nelson, R. Barbosa, Research on social data by means of cluster analysis, In
Applied Computing and Informatics 15(2) (2019) 153-162.

[7] M. Barry, Reflections on Identifying and Mapping Learning Competencies and Outcomes: What Do We Want Law Students to Learn? 62 N.Y.L. SCH. L. REV., 2018, 131 p.

[8] O.A. Makarova, A.A. Shabanova, Criteria and levels of building the professional competence of future lawyers in the context of a foreign language, In Bulletin of Perm National Scientific and Technical University. Problems of linguistics and education (3) (2020) 124-135

[9] B. Rakhmonov, Analysis of the list of components of professional competence of future teachers of the Russian language, In European Journal of Research and Reflection in Educational Sciences 7(7) (2019) 51-56.

[10] Yu. G. Tatur, How to increase the objectivity of ranging and assessment of education, In Ekonomika obrazovaniya [Education economics] (1) (2011) 60-67.

[11] R. Ryan, E. Deci, Intrinsic and extrinsic motivation from a self-determination theory perspective: Definitions, theory, practices, and future directions, In Contemporary Educational Psychology, 2020, P. 61. DOI: https://doi.org/10.1016/j.cedpsych.2020.101860

[12] O.A. Makarova, M.A. Kovardakova, Situational approach as a concrete definition of the personaloriented paradigm of vocational education, Society of Russia; educational space psychological structures and social values 8(6-2) (2017) 128-137.

[13] M. Harsel, V. Hoogerheide, P. Verkoeijen, T. Gog, Effects of different sequences of examples and problems on motivation and learning, In Contemporary Educational Psychology, 2019, pp. 260-275. DOI: https://doi.org/10.1016/j.cedpsych.2019.03.005

[14] Solicitors Regulation Authority. Retrieved from: https://www.sra.org.uk/solicitors/standardsregulations 